\title{
Reply to Letter to the Editor "Polypharmacy in elderly people with diabetes admitted to hospital"
}

\author{
Marianna Noale $^{1} \cdot$ Nicola Veronese $^{2} \cdot$ Paolo Cavallo Perin $^{3} \cdot$ Alberto Pilotto $^{4}$. \\ Antonio Tiengo ${ }^{2} \cdot$ Gaetano Crepaldi $^{1} \cdot$ Stefania Maggi $^{1}$
}

Received: 6 November 2015/Accepted: 6 November 2015/Published online: 25 November 2015

(C) Springer-Verlag Italia 2015

\section{Dear Editor,}

We would like to thank Dr. Formiga and colleagues for their comments about our paper. As they state in their Letter to the Editor, there are many important differences between the population in the METABOLIC Study [1] and in the PIPOPS Project [2] (Table 1). As a result, the mean number of prescribed drugs reported by Formiga F. et al. for DM patients is more than double than that we reported in our study (12.6 \pm 4.5 vs. $4.8 \pm 1.8)$. As observed by Formiga F. et al., the higher percentage of polypharmacy found in their study might be explained considering that their DM patients were older, more seriously ill and with more comorbidities, including cognitive impairment.

We think that the conclusion reported by Formiga in the Letter to the Editor, stating that elderly patients with DM show a high degree of polypharmacy, with three quarters of them taking 10 or more drugs on a daily basis should be clarified by specifying that the data refer to hospitalized patients, with reference to the drugs taken in the month prior to hospitalization. However, we completely agree with Formiga F. et al. that polypharmacy is often connected with multimorbidity in DM patients and that a periodic

Managed by Massimo Porta.

Marianna Noale

marianna.noale@in.cnr.it

1 CNR, Institute of Neuroscience, Aging Branch, Padua, Italy

2 Department of Medicine, University of Padua, Padua, Italy

3 Diabetology Unit, University of Turin, Turin, Italy

4 Department of OrthoGeriatrics, Rehabilitation and Stabilization, Frailty Area, E.O. Galliera Hospital, National Relevance and High Specialization Hospital, Genoa, Italy
Table 1 Main differences among METABOLIC study and PIPOPS project populations

\begin{tabular}{|c|c|c|}
\hline & $\begin{array}{l}\text { Formiga F. et al. } \\
\text { "Inappropriate prescribing } \\
\text { in elderly people with } \\
\text { diabetes admitted to } \\
\text { hospital" Diabetic } \\
\text { Medicine, } 2015\end{array}$ & $\begin{array}{l}\text { Noale M. et al. } \\
\text { "Polypharmacy in elderly } \\
\text { patients with type } 2 \\
\text { diabetes receiving oral } \\
\text { antidiabetic treatment" }\end{array}$ \\
\hline $\begin{array}{l}\text { Sample } \\
\text { size }\end{array}$ & $\begin{array}{l}n=672 \text { subjects, among } \\
\text { which } n=249 \text { with DM }\end{array}$ & $\begin{array}{l}n=1342 \text { subjects with } \\
\text { DM }\end{array}$ \\
\hline Age & $\begin{array}{l}75 \text { Years or more } \\
\text { Mean age: } 82.4 \text { years }\end{array}$ & $\begin{array}{l}65 \text { Years or more } \\
\text { Mean age: } 73.3 \text { years }\end{array}$ \\
\hline Setting & $\begin{array}{l}\text { Subjects admitted to } \\
\text { hospital }\end{array}$ & $\begin{array}{l}\text { Subjects enrolled in } \\
\text { diabetes centers, with a } \\
\text { diagnosis of type } 2 \text { DM, } \\
\text { treated with oral } \\
\text { antidiabetic drugs }\end{array}$ \\
\hline $\begin{array}{c}\text { Selection } \\
\text { criteria }\end{array}$ & $\begin{array}{l}\text { The pharmacological } \\
\text { anamnesis was made also } \\
\text { for cognitively impaired } \\
\text { patients, asking to their } \\
\text { relatives the number and } \\
\text { the type of prescription } \\
\text { medicines }\end{array}$ & $\begin{array}{l}\text { The inability to consent to } \\
\text { participate in the study } \\
\text { protocol was considered } \\
\text { as an exclusion criteria }\end{array}$ \\
\hline
\end{tabular}

review of their treatments should be encouraged to reduce inappropriate use of drugs.

\section{Compliance with ethical standards}

Conflict of interest The authors declare that they have no conflict of interest.

Ethical standard The study was approved by ethics review committees of each participating center.

Human and animal rights disclosure All procedures followed were in accordance with the ethical standards of the responsible 
committee on human experimentation (institutional and national) and with the Declaration of Helsinki 1975, as revised in 2008 (5)

Informed consent disclosure Informed consent was obtained from all patients for being included in the study.

\section{References}

1. Noale M, Veronese N, Cavallo Perin P et al (2015) Polypharmacy in elderly patients with type 2 diabetes receiving oral antidiabetic treatment. Acta Diabetol. doi:10.1007/s00592-015-0790-4
2. Formiga F, Vidal X, Agustí A et al (2015) Potentially Inappropriate Prescription in Older Patients in Spain (PIPOPS) Investigators' Project. Inappropriate prescribing in elderly people with diabetes admitted to hospital. Diabet Med. doi:10.1111/dme.12894 